\title{
Job Satisfaction of Librarians of African Descent Employed in ARL Academic Libraries
}

\author{
Joyce K. Thornton
}

Job satisfaction is critical to the retention and recruitment of librarians. This study examines job satisfaction of librarians of African descent employed at academic libraries holding membership in the Association of Research Libraries. The results of a three-part job satisfaction survey are presented. The survey identifies areas of satisfaction and dissatisfaction for this group of librarians. There has been no significant gain in the number of librarians of African descent in ARL academic libraries in the past ten years. If libraries are to recruit and retain a diverse workforce, consideration must be given to what makes these employees remain on the job and in the profession.

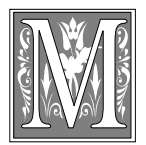

any writers have suggested that by the turn of the century, the majority of the U.S. population will be members of four racial and ethnic groups-African Americans, Latinos, Asian Americans, and Native Americans. We can readily observe that these demographics are already being felt in the workplace. Moreover, this new majority is forcing changes in the traditional makeup of student populations at many institutions of higher education. Thus, it follows that the faculty and staffs of these institutions should reflect the population they serve.

In libraries with predominantly white staffs, librarians of African descent are in a somewhat unique position. Some may have added pressures. They may face attitudes about their abilities to do a job well or have peers who feel that they have been given the job because of their skin tone. And in libraries where only one librarian of African descent is on the staff, they may feel isolated. These and other factors may affect the level of satisfaction that librarians of African descent derive from their jobs. There is a paucity of research on job satisfaction of African Americans overall and of those in academia in particular. This article examines factors, already established, that contribute significantly to job satisfaction of librarians of African descent at ninety-six U.S. academic libraries that are members of ARL. In addition, the study examines six factors of concern to librarians of African descent to determine their significance to job satisfaction. The survey excluded deans and directors.

\section{Cause for Concern}

Carol Patitu and Martha Tack stated that "without a doubt, the continuing absence, not presence, of African American faculty, who represent the largest minority group in higher education's faculty rank has be-

Joyce K. Thornton is Director for Specialized and Distance Library Services in the Sterling C. Evans Library at Texas AEM University; e-mail: JKTHORN@tamu.edu. 
TABLE 1

Minority Librarians at U. S. ARL Academic Libraries

\begin{tabular}{lccccc}
\hline \hline Year & $\begin{array}{c}\text { Total Filled } \\
\text { Positions }\end{array}$ & $\begin{array}{c}\text { No. of Minority } \\
\text { Librarians }\end{array}$ & $\begin{array}{c}\text { No. in Academic } \\
\text { Libraries }\end{array}$ & $\begin{array}{c}\text { No. in Medical } \\
\text { and Law } \\
\text { Libraries }\end{array}$ & $\begin{array}{c}\text { Total No. of } \\
\text { Librarians of } \\
\text { African Descent }\end{array}$ \\
\hline $1987-88$ & 7,248 & 735 & 635 & 100 & 231 \\
$1988-89$ & 7,354 & 756 & 651 & 105 & 248 \\
$1989-90$ & 7,444 & 791 & 670 & 121 & 274 \\
$1990-91$ & 7,654 & 818 & 699 & 119 & 272 \\
$1991-92$ & 7,520 & 804 & 689 & 115 & 248 \\
$1992-93$ & 7,484 & 802 & 687 & 115 & 272 \\
$1993-94$ & 7,318 & 830 & 710 & 120 & 276 \\
$1994-95$ & 7,411 & 841 & 724 & 117 & 274 \\
$1995-96$ & 7,435 & 842 & 723 & 119 & 262 \\
$1996-97 *$ & 7,561 & 853 & 721 & 132 & 279 \\
*Based on ninety-six U.S. members (Ohio University became a member, adding six minority \\
librarians).
\end{tabular}

come a national issue."1 William B. Harvey asked: "Where are the Black faculty?"2 The question of concern that prompted this study is, Where are the librarians of African descent? Earl Smith and Stephanie Witt, in a study conducted to compare occupational stress among African American and white university faculties, sounded an alarm regarding the number of African American faculty presently employed and the fewer numbers that will be employed on university campuses in the future. ${ }^{3}$ Their alarm sounded a wake-up call for libraries, as well. Table 1 shows the representation of minority librarians at ARL universities in the United States for the past ten years. (The thirteen Canadian academic libraries are excluded because Canadian law prohibits identification of $\mathrm{Ca}$ nadians by ethnic category.) ${ }^{4}$

Jan S. Squire has reiterated the fact that there is, and continues to be, considerable underrepresentation of specific racial and ethnic groups in the library workforce. She listed the reasons as: a lack of ethnic minority graduate students in information and library science (LIS) programs, a lack of recruitment and affirmative action policies in libraries, and an inability to retain ethnic minorities on staff. ${ }^{5}$ Concerted efforts are made to recruit minorities to in- stitutions, but equal efforts are not made to retain them. The recruitment, retention, and advancement of people of color in the library profession are important to the long-term future of libraries. Meredith A. Butler and Gloria R. DeSole stated that "it is in the highest self-interest of all libraries, but especially of our academic and research libraries, to reflect the diversity of our rapidly changing world. Libraries that do not have librarians, staff, collections, and a welcoming atmosphere for one third of this nation will find it difficult to justify their relevance as serving the needs of their clientele." 6 Table 1 also shows that from 1987 to 1996, only forty-eight African American librarians were added to the ninety-six ARLs. These numbers highlight the continuing severe underrepresentation of librarians of African descent in academic libraries and in the library and information science profession.

Job advertisements show that some universities (e.g., University of Minnesota, Auburn University, Yale University, Ohio State, Iowa State, University of California at Santa Barbara, University of New Mexico, University of Michigan) have established residency/post-master's internship programs designed to increase the number of minority librarians in aca- 
demic research libraries and/or to promote the growth and development of minority librarians within the profession. At its 1997 midwinter meeting, the ALA unveiled its Spectrum Initiative proposal. According to DeEtta Jones, the initiative addresses "the underrepresentation of critically needed minority librarians

\section{If libraries are not only to recruit but also retain a diverse workforce, consideration must be given to what makes these employees remain on the job and in the profession.}

within the profession" by proposing that five graduate library education schools create a consortium in an effort to graduate 150 racially diverse librarians in three years. The proposal highlights the disproportionately low numbers of racially diverse individuals graduating from LIS schools and concludes that the library profession as a whole is losing ground in recruiting minorities to LIS professions while the ethnic makeup of the United States continues to change. ARL's own diversity program is founded on the belief that only by adding different perspectives and talents to the research library profession will such libraries continue to be the vibrant and evolving institutions needed for the increasingly diverse communities of the twenty-first century. ${ }^{7}$ If libraries are not only to recruit but also retain a diverse workforce, consideration must be given to what makes these employees remain on the job and in the profession. Surely, satisfaction with one's job is a most compelling factor.

\section{Review of the Literature}

Job satisfaction is one of the more widely discussed topics in the literature and the workplace. Many definitions of job satisfaction exist, including:

- Job satisfaction is a dynamic changing idea that reflects an individual's attitudes and expectations toward his work and goals in life. ${ }^{8}$

- Job satisfaction is the feeling an employee has about his pay, work, pro- motion opportunities, coworkers, and supervisor. $^{9}$

- Job satisfaction refers to the feelings and emotional aspects of individuals' experiences toward their jobs, as different from intellectual or rational aspects. ${ }^{10}$

In 1985, Paul E. Spector calculated that approximately 4,793 articles had been written on job satisfaction. ${ }^{11}$ If a count of relevant articles and dissertations were made today, that number would certainly be well over six thousand. The LIS field is contributing to this growth.

Prior to 1970, no studies were found specifically about job satisfaction and librarians; however, two studies on job turnover of librarians cited factors such as low pay, job duties, and lack of promotion as reasons for high turnover. ${ }^{12}$ These factors now are considered as pertaining to job satisfaction. In 1983, Beverly Lynch and Jo Ann Verdin identified ten studies on various aspects of job satisfaction in libraries. These studies attempted to identify the factors most highly related to job satisfaction. Of the ten studies, two were concerned with satisfaction in specific libraries. One compared libraries or library units, and one investigated satisfaction of all occupational groups within the library. Lynch and Verdin's study explored the correlates of job satisfaction within the work setting. It suggested that significant variations in job satisfaction occur among functional units in libraries and among occupational groups. ${ }^{13}$

The 1987 replication of Lynch and Verdin's study supported their earlier findings. ${ }^{14}$ Other studies shed further light on the job satisfaction of librarians. Ilene F. Rockman's study suggested that job satisfaction is a function of more than just gender or membership in a dominant work group and that autonomy and decision-making opportunities can affect job satisfaction. ${ }^{15}$ Carol Saunders and Russell Saunders measured the effect of flextime on several variables, including satisfaction. They concluded that job satisfaction has more powerful factors than a work schedule. ${ }^{16}$ Dale Susan Bengston and Dor- 
othy Shields tested and supported Maurice Marchant's theory that management style is a predictor of job satisfaction. ${ }^{17}$

\section{Job Satisfaction Studies in Other Countries}

Librarians in other countries also have reported research on job satisfaction studies. In a general satisfaction survey of one hundred librarians of Lucknow City, Kamala Chopra found that librarians derived satisfaction from their work, social recognition received, working conditions, job security, and social status. Sources of dissatisfaction were from avenues for promotion, behavior, and pay scales. ${ }^{18}$ When Brigg Nzotta studied the factors associated with the job satisfaction of male and female librarians in Nigeria, he found that women derived greater job satisfaction from their work than their male counterparts. Women were more satisfied with independence, security, ability utilization, and working conditions. On the other hand, men were more satisfied with variety. ${ }^{19}$ In a second study on general satisfaction of Nigerian librarians, Nzotta found that (1) librarians in management were more satisfied than public or technical services librarians with regard to variety, responsibility, and creativity derived from their job; and (2) librarians in management and public services were more satisfied than technical services librarians with the social status aspect. ${ }^{20}$

\section{It cannot be taken for granted that the major correlates of job satisfac- tion for librarians of African descent and white librarians are the same.}

J. F. Shyu studied the level of job satisfaction at sixteen university libraries in the Republic of China. The data suggested that the staffs had not achieved satisfaction on their jobs. Neither the educationallevel, department affiliation, nor marital status variables showed significant differences among the respondents in job satisfaction. Sex, age, professional education, tenure, career orientation, and supervi- sory level affected job satisfaction. ${ }^{21}$ David Waters assessed the impact of new technology on job satisfaction, prestige, selfesteem, and social relationships at the University of Tasmania. He concluded that technological change had not been a major force for job dissatisfaction. Job dissatisfaction, where it exists, seemed to be largely independent of the introduction of new technology.2 In a study of correlation between job satisfaction, job attitudes, and work behavior among staff members in academic libraries in Nigeria, Edet E. Nkeuweren supported the proposition that management style and quality of work life affect job satisfaction and that overall job satisfaction is a function of many needs. The results also indicated that Nigerian library staffs responded positively to monetary rewards as incentives to improve job attitude and work performance. Factors outside the work environment also affect the level of Nigerian library staffs' job satisfaction. ${ }^{23}$

\section{Recent Studies}

Beginning around the mid-1980s, job satisfaction studies in libraries began to examine the relationships between job satisfaction and other interventions, including continuing education needs; automation; unionization; performance; and job responsibilities. ${ }^{24-28} \mathrm{~A}$ number of studies on job satisfaction of professional/support/clerical staff began to appear in the literature..$^{29}$ Specific studies on job satisfaction and public libraries began to appear that included general job satisfaction studies, job satisfaction and stress, changing climate, and goal setting. ${ }^{30}$

Mohammad H. Mirfakhrai studied correlates of job satisfaction among librarians in the U.S. He concluded that academic librarians in both smaller and larger libraries had a positive perception of their jobs. There was no significant relationship between sex of academic librarians and their overall satisfaction in bothsized libraries. The nature of work, supervision, salary, promotion, and coworkers was highly correlated with the over- 
all job satisfaction of academic librarians in both smaller and larger libraries. Age, experience, and length of employment with the present institution were negatively correlated with overall job satisfaction in both-sized libraries; and academic librarians in both smaller and larger libraries were least satisfied with promotional opportunities. ${ }^{31}$

In a thorough examination of the literature, Squire looked at job satisfaction and the ethnic minority and located a small body of literature that pertained to job satisfaction and ethnicity, but job satisfaction was not specifically covered. ${ }^{32}$

In their study of job satisfaction and automation, Leigh Estabrook, Chloe Bird, and Frederick Gilmore reported that "race is the second largest factor in explaining job satisfaction. Whites are significantly more satisfied with their jobs. This finding is disturbing, for it suggests that libraries do not treat minority workers equally." ${ }^{\prime 33}$ Cynthia Preston conducted a study on perceptions of discriminatory practices and attitudes in the workplace and how they influenced job satisfaction. Her study focused on relationships with supervisors, patrons, coworkers, and management. She concluded that racism by itself is not a significant and recognizable determinant of job satisfaction or dissatisfaction. ${ }^{34}$

In summary, the review of the literature shows that although the number of studies on job satisfaction in libraries continues to grow, examination of job satisfaction of librarians of African descent is a realm that has remained relatively unexplored. It cannot be taken for granted that the major correlates of job satisfaction for librarians of African descent and white librarians are the same. There is a critical need for additional research on the job satisfaction of minorities, especially librarians of African descent.

\section{Methodology}

A three-part survey instrument was developed, partially based on surveys found in the literature. A standard instrument was not used because none addressed several factors of concern to librarians of African descent, such as diversity, isolation, or hostility issues. A pilot survey was sent to librarians of African descent in Texas, Mississippi, California, Pennsylvania, and New York. Part I of the questionnaire obtained information about the respondents' age, gender, education, faculty status as defined by their institutions, tenure, rank, years in the profession, years in present position, salary, and area of service. Part II of the questionnaire solicited information regarding the respondents' perception of the work environment. This section solicited information on isolation, diversity, decision making, and participation in university- and library-related activities. Part III consisted of twenty-three items on overall satisfaction. Respondents indicated satisfaction in each of the areas by selecting a response from a Likert-type five-point scale based on a similar survey used by Bonnie Horenstein in her study on job satisfaction of academic librarians. ${ }^{35}$ Respondents also were asked to rank factors that would influence their decision to leave and to list occurrences in their current job that contributed significantly to feelings of satisfaction and dissatisfaction.

In an attempt to obtain the most accurate (if such exists) number of librarians of African descent employed at ARL academic libraries, a letter explaining the project and asking for the names of librarians of African descent was sent to the deans/directors at the ninety-six U.S. ARL academic libraries. Seventeen directors responded that there were no librarians of African descent at their institutions. Fifty-two directors responded with names. Five were reluctant to give names and asked that the surveys be sent to them. A follow-up call was then made to the personnel/human resources directors at the twenty-two remaining institutions. An offer was made to send surveys to personnel/human resources directors if providing names was a problem. For surveys sent to personnel/human resources directors, a cover letter was included regarding the project. Eighteen deans/direc- 
tors/personnel officers indicated an interest in seeing the results of the survey. The seventy-nine institutions reported a total of 216 librarians of African descent. The 1996-1997 ARL Annual Salary Survey indicated that there were 279 Black librarians at the ninety-six U.S. academic libraries. ${ }^{36}$ The difference in the numbers may be attributed to the facts that ARL uses the term black rather than librarians of African descent, the term used by the author; ARL's data are for filled positions as of July 1, 1997; and ARL asked for all professional positions rather than the accredited library masters. Two hundred and sixteen surveys were mailed in March, with a requested return date of April 23, 1998.

By the requested return date, 111 surveys had been returned from the seventynine institutions. A follow-up letter with another survey was sent to those individuals for whom names were given and a message was posted on one listserv. By June 30 , an additional thirty-five surveys were received. The 146 of 216 returned surveys represented a 67 percent return rate. Two surveys from library deans were not used. Of the 144 surveys, the eight received from Howard University, the only Historically Black College or University (HBCU), were excluded. Responses from the 136 surveys were analyzed. Numbers were assigned to each response category for each question. The SPSS for Windows statistical program was used to analyze the responses.

Table 2 reflects some of the responses from the demographic section. Of the 134 respondents to the age question, 84 percent (115) were 35 years old and older. These numbers show a need for strong recruitment of younger people to the profession. Seventy-three percent (99) of the 129 respondents to the gender question were female. This percentage is close to the number reported by the ARL statistics, which reflects that women make up 72.64 percent of the librarians in the four racial groups that comprise minority staff (Black, Hispanic, Asian/Pacific Islanders, American Indian/Native Alaskan).
Ninety-six percent of the respondents (129) were full-time librarians. Slightly more than 43 percent (59) had faculty status. Of the 64 responses regarding faculty rank, 13 percent (8) were instructors, 19 percent (12) were assistant professors, 27 percent (17) were associate professors, 6 percent (4) were professors, and 36 percent (23) listed other. More than half (68) responded "not applicable." Some of the titles given in the "other" category included assistant university librarian; librarian II, III, and IV; deputy librarian, administrator, curator, visiting instructor, visiting minority scholar, general librarian, temporary librarian, and EPA-nontenured faculty. Less than 35 percent (47) indicated that full-time librarians were eligible for tenure, and about 20 percent (27) were tenured.

Of the 132 responses to the question regarding total years as a professional librarian, 61 percent (81) had been in the profession ten years or longer. The average is fifteen years, close to ARL's average years of experience for minority librarians as 16.1 years. Surprisingly, of the 135 responses, 18 percent (24) had been at the same institution more than fifteen years and 19 percent (25) had been at the same institution for ten to fifteen years. Of the 135 responses regarding salary, 48 percent (65) earn more than $\$ 40,000$.

Over three percent of the 135 respondents were black, not African American, and 4.4 percent listed themselves as other; almost 71 percent (96) of the 135 respondents held an MLS or a master's degree; 24 percent (32) held an additional master's.

Reference ranked highest as area of service with 30.9 percent (42) of the 109 respondents listing it as their department or area of service. The ARL statistics reported that 31.5 percent of minority librarians work in reference. The second largest area of service was the "other" category at 24 percent (26). "Other" included media, archives, interlibrary loan, branch head librarian, collection development, departmental librarian, digital librarian, diversity librarian, special collections, bib- 
TABLE 2

Demographic Data on the Respondents

( $\mathrm{N}=$ Number of respondents)

\begin{tabular}{lr}
\hline Age & N \\
\hline under 25 & 1 \\
$25-34$ & 18 \\
$35-44$ & 49 \\
$45-54$ & 57 \\
Over 55 & 9 \\
No response & 2
\end{tabular}

\begin{tabular}{lr} 
Tenured & N \\
\hline Yes & 27 \\
No response & 29 \\
Not applicable & 78 \\
No response & 2
\end{tabular}

\begin{tabular}{lc} 
Gender & N \\
\hline Male & 30 \\
Female & 99
\end{tabular}

Years as a Professional

\begin{tabular}{lr} 
Librarian & N \\
\hline $0-3.9$ & 29
\end{tabular}

$4-9.9 \quad 22$

10-15 34

No response 7

Over 15

No response 3

\begin{tabular}{lc} 
Education & N \\
\hline MLS/MA & 96
\end{tabular}

Years at Present

Additional MA 32

Ph.D. 2

Other 5

No response 1

\begin{tabular}{ll} 
Full-Time Librarian & N \\
\hline Yes
\end{tabular}

\begin{tabular}{lr}
\hline Yes & 129 \\
No & 5 \\
No response & 2
\end{tabular}

Institution

Less than 1 year 13

$1-3.9 \quad 35$

$4-9.9 \quad 38$

10-15 25

More than $15 \quad 24$

No response 1

No response 2

\begin{tabular}{lc} 
Faculty Status & N \\
\hline Yes & 59 \\
No & 77
\end{tabular}

Salary

$\$ 25,001-\$ 30,000 \quad 16$

$\$ 30,001-\$ 35,000 \quad 27$

$\$ 35,001-\$ 40,000 \quad 25$

$\$ 40,001-\$ 45,000 \quad 23$

\begin{tabular}{lc} 
Faculty Rank & N \\
\hline Instructor & 8
\end{tabular}

More than $\$ 45,000$

No response 1

Asst. professor $\quad 12$

Assoc. professor $\quad 17$

Professor 4

Other 23

Not applicable $\quad 68$

No response 3

\begin{tabular}{ll} 
Area of Service & N \\
\hline Acquisitions & 3
\end{tabular}

Cataloging 9

Automated Systems 3

Reference 42

Serials 1

Administration 20

Circulation 5

Other 26

No response

11

78

No response 
liographer, library instructor, government publications, cultural activities, technical services, undergraduate services, data services, access services, African American studies librarian, and preservation. Eighteen percent (20) of the respondents listed administration as their area of service. Less than one percent were in serials. The author recommends that future surveys provide more job categories as possible choices for the participants.

Part II of the questionnaire asked respondents to answer nineteen perceptional questions by selecting "No Opinion," "Not at All," "Little," "Moderately," or "To a High Degree." Table 3 reports the number of responses to the perception questions. Sixty percent of the respondents who expressed an opinion felt that their involvement in library- and / or university-related committees had nothing or little to do with their race, compared to 32 percent who felt moderately and to a high degree that they were involved because of race. Eighty-two percent of the respondents felt moderately and to a high degree that their knowledge was respected. Fifty-two percent felt no or little external pressure to overachieve, compared to 40 percent who felt, moderately and to a high degree, external pressure to overachieve. And 74 percent felt, moderately and to a high degree, self-induced pressure to achieve.

Three questions were asked regarding isolation. Forty-one percent (56) of the respondents perceived a moderate to high degree of isolation at the institution, and 34.5 percent (47) perceived a moderate to high degree of isolation in the workplace. Nineteen percent (26) of the respondents indicated that isolation affected their performance. Forty-one percent (56) of the respondents felt that they must try to fit into the work environment. Joan Howland has suggested that "it simply is neither logical nor good business practice to recruit and hire librarians from diverse backgrounds, only to expect them to assimilate and become mirrors of the generations of librarians which have preceded them. ${ }^{137}$ Although, overall, respon- dents felt support at work, 13 percent (18) felt that the work environment was hostile and 26 percent (36) had experienced incidences of racial discrimination in the workplace. In her study of perceptions of discriminatory practices and attitudes, Preston asked participants if they had observed racial discrimination in their work environment and found that 51 percent had..$^{38}$

The three questions regarding diversity revealed that although the library administration is somewhat committed to diversity $(52 \%)$, and welcomes and values it $(54 \%)$, the diversity programs were not adequate $(60 \%)$. This suggests that libraries are not practicing what they preach regarding diversity and there may be no evident commitment to it. Fortythree percent (58) agreed that the standards of performance were the same for all librarians, 25 percent (34) felt that there was a little difference, and 23 percent (31) felt, moderately and to a high degree, that the standards of performance were different. More than 40 percent (55) of the respondents felt that they could seek positions at the top of their organizations and not fear constant attack, but 43 percent (59) felt they could not. When asked if they felt left out of the decision-making process, 36.8 percent (50) of the respondents indicated moderately to a high degree, 25.7 percent (35) indicated a little, 33.8 percent (46) indicated not at all, and 3.7 percent (5) had no opinion. Although 63.3 percent (86) of the respondents felt little or no pressure to conduct and publish scholarly research, 33 percent (45) did. Fifty-three percent (72) of the 135 respondents indicated that their colleagues were willing to assist them in research endeavors, and 31 percent (42) responded little or not at all. The willingness to assist colleagues in research endeavors can be very significant to promotion and professional growth. The veteran colleague can provide assistance in helping with committee appointments, collaborative projects, and professional development activities, and can serve as a confidence booster. Directors wishing to retain more librar- 
TABLE 3

Perceptional Questions

\section{Part II: To What Extent Do You Feel...}

No Not at

That you are involved in library- and/or university-related committees/meetings because you are of African descent?

That there is respect for your knowledge?

External pressure to overachieve?

Self-induced pressure to overachieve?

Isolated at your institution?

Isolated in your workplace?

Unsupported at work?

That isolation (if any) affects your work performance?

That you must try to fit into your work environment?

That your work environment is hostile toward you?

Opinion

Not at

Little

Moderately

To a High

Total No. of

Degree

Responses

That you have experienced incidences of racial discrimination

in the workplace?

That your library administration has a high degree of commitment

to diversity?

That your library has an adequate librarywide diversity program?

That your library welcomes and values diversity?

$\begin{array}{rrrrrr}11 & 50 & 31 & 30 & 14 & 136 \\ 2 & 4 & 19 & 54 & 57 & 136 \\ 10 & 30 & 41 & 32 & 23 & 136 \\ 3 & 12 & 20 & 52 & 49 & 136 \\ 1 & 44 & 35 & 34 & 22 & 136 \\ 2 & 56 & 31 & 29 & 18 & 136 \\ 5 & 69 & 29 & 24 & 9 & 136 \\ 16 & 59 & 35 & 24 & 2 & 136 \\ 3 & 43 & 34 & 36 & 20 & 136 \\ 1 & 79 & 38 & 11 & 7 & 136 \\ & & & & & \\ 9 & 41 & 50 & 23 & 13 & 136 \\ & & & & & \\ 5 & 16 & 44 & 49 & 22 & 136 \\ 16 & 44 & 38 & 29 & 9 & 136 \\ 6 & 11 & 45 & 57 & 17 & 136 \\ 12 & 58 & 34 & 15 & 16 & 135 \\ 22 & 21 & 38 & 30 & 25 & 136 \\ 5 & 46 & 35 & 30 & 20 & 136 \\ 5 & 56 & 30 & 26 & 19 & 136 \\ 21 & 15 & 27 & 42 & 30 & 135 \\ & & & & & \end{array}$

different from those applied to non-African American librarians?

That you can seek a position at the top of your organization

and not fear constant attack?

That you feel left out of the decision-making process?

Pressured to conduct and publish scholarly research?

That your colleagues are willing to assist you in your research endeavors? 21 


\section{TABLE 4}

Job Satisfaction

Indicate your satisfaction with each of the following aspects of your current position by checking the most correct response.

\begin{tabular}{|c|c|c|c|c|c|c|}
\hline & \multicolumn{6}{|c|}{ Percent of Respondents } \\
\hline & $\begin{array}{l}\% \text { Very } \\
\text { Oissatisfied }\end{array}$ & $\%$ Dissatisfied & $\begin{array}{c}\% \text { Can't } \\
\text { Decide or } \\
\text { Neutral }\end{array}$ & $\%$ Satisfied & $\begin{array}{c}\% \text { Very } \\
\text { Satisfied }\end{array}$ & $\begin{array}{c}\text { No. of } \\
\text { Responses }\end{array}$ \\
\hline Job duties & 2.9 & 7.4 & 2.9 & 54.4 & 28.7 & 131 \\
\hline Working conditions & 2.9 & 6.6 & 14.0 & 50.7 & 24.3 & 134 \\
\hline Autonomy on the ob & 2.2 & 3.7 & 11.8 & 49.3 & 30.9 & 133 \\
\hline Challenges of the ob & .7 & 8.1 & 8.8 & 46.3 & 32.4 & 131 \\
\hline Variety of occupational tasks & & 7.4 & 7.4 & 50.7 & 32.4 & 133 \\
\hline Work assignment and workload & 4.4 & 14.7 & 11.8 & 52.9 & 15.4 & 135 \\
\hline Job security & 2.2 & 6.6 & 17.6 & 47.1 & 25.0 & 134 \\
\hline Interaction with peers & .7 & 11.0 & 18.4 & 51.5 & 16.9 & 134 \\
\hline Interaction with patrons & .7 & .7 & 11.0 & 52.2 & 30.1 & 129 \\
\hline Status of librarians at your institution & 3.7 & 15.4 & 24.3 & 37.5 & 16.2 & 132 \\
\hline Salary & 12.5 & 31.6 & 8.8 & 36.0 & 9.6 & 134 \\
\hline Fringe benefits & 4.4 & 11.0 & 15.4 & 41.9 & 25.7 & 134 \\
\hline Opportunities for advancement & 8.1 & 23.5 & 33.1 & 23.5 & 10.3 & 134 \\
\hline Opportunities for collegial interaction within your department & 3.7 & 9.6 & 18.4 & 45.6 & 19.1 & 133 \\
\hline Opportunities for collegial interaction with faculty in other departments & nts 3.7 & 14.0 & 29.4 & 36.8 & 12.5 & 133 \\
\hline Opportunities for professional development & 2.9 & 9.6 & 11.0 & 43.4 & 30.1 & 132 \\
\hline Interest of department colleagues in your work & 2.9 & 14.7 & 35.3 & 36.8 & 8.8 & 134 \\
\hline Opportunities to pursue research & 1.5 & 13.2 & 25.7 & 33.8 & 19.1 & 130 \\
\hline Proportion of faculty of African descent at the university & 35.3 & 40.4 & 16.2 & 5.1 & .7 & 134 \\
\hline Proportion of faculty of African descent in the library & 44.1 & 35.3 & 11.0 & 5.1 & .7 & 132 \\
\hline Manner in which administration handles problems & 7.4 & 14.0 & 51.5 & 16.2 & 3.7 & 128 \\
\hline Lines of communication & 8.8 & 24.3 & 16.9 & 44.9 & 3.7 & 134 \\
\hline Serving as role model for students of African descent & 1.5 & 7.4 & 35.5 & 35.3 & 18.4 & 133 \\
\hline
\end{tabular}


ians may wish to encourage mentoring and coauthoring.

Table 4 reveals that, overall, respondents were most satisfied with job duties, variety of occupational tasks, interaction with patrons, autonomy, challenges of the job, working conditions, professional development, and job security. More than 70 percent of the respondents indicated that they were satisfied and very satisfied with these aspects of the job. However, respondents were dissatisfied to very dissatisfied with the proportion of faculty of African descent in the library $(79.4 \%)$ and at the institution $(75.7 \%)$. Forty-four percent were dissatisfied with salary, which was one of the traditional sources of dissatisfaction identified by other studies. Thirtythree percent were dissatisfied with lines of communication and 31.6 percent with opportunities for advancement. Fifty percent of the 128 respondents could not decide or were neutral on the question regarding the manner in which the administration handles faculty problems.

The author looked at four control factors (age, gender, years as a professional librarian, and years at present institution) in relation to six factors of concern to li- brarians of African descent. The six factors were: (1) isolation in the workplace; (2) isolation at the institution; (3) isolation as it affects performance; (4) incidences of racial discrimination; (5) hostile work environment; and (6) adequacy of the library's diversity program.

As indicated in table 5, twenty of the fifty-seven respondents in the 45-54 age group felt a moderate to high degree of isolation in the workplace, and twenty-five felt a moderate to high degree of isolation at the institution. In the 35-44 age group, eighteen of the forty-nine respondents felt a moderate to high degree of isolation in the workplace and twenty-one felt a moderate to high degree of isolation at the institution. Eleven of the fifty-seven respondents in the 45-54-age group and eight of the forty-nine respondents in the 35-44 age group responded that isolation affected their performance. Seventeen of the 45-54 group and thirteen of the 35-44 age group reported experiencing incidences of racial discrimination. Nine of the respondents in the 45-54 age group responded experiencing a hostile work environment. Thirtyfour respondents in the 45-54 age group and twenty-eight in the 35-44 age group

\begin{tabular}{|c|c|c|c|c|}
\hline \multicolumn{5}{|c|}{$\begin{array}{c}\text { TABLE } 5 \\
\text { Number and Percent of Respondents in Each Age Group } \\
\text { and the Six Factors of Concern }(N=134) \\
\end{array}$} \\
\hline $\begin{array}{l}\text { Age } \\
\text { Total No. of Respondents* }\end{array}$ & $\begin{array}{c}25-34 \\
19\end{array}$ & $\begin{array}{c}35-44 \\
49\end{array}$ & $\begin{array}{c}\mathbf{4 5}-\mathbf{5 4} \\
\mathbf{5 7}\end{array}$ & $\begin{array}{c}55+ \\
9\end{array}$ \\
\hline \multicolumn{5}{|l|}{ Question: To what extent do you feel... } \\
\hline Isolated in your workplace? & $5(26 \%)$ & $18(37 \%)$ & $20(35 \%)$ & $3(33 \%)$ \\
\hline Isolated at the institution? & $5(26 \%)$ & $21(43 \%)$ & $25(38 \%)$ & $4(44 \%)$ \\
\hline $\begin{array}{l}\text { That isolation (if any) affects your } \\
\text { work performance? }\end{array}$ & $4(21 \%)$ & $8(16 \%)$ & $11(19 \%)$ & $3(33 \%)$ \\
\hline $\begin{array}{l}\text { That you have experienced incidences of } \\
\text { racial discrimination in the workplace? }\end{array}$ & $3(16 \%)$ & $13(26 \%)$ & $17(30 \%)$ & $2(22 \% 0$ \\
\hline $\begin{array}{l}\text { That your work environment is hostile } \\
\text { toward you? }\end{array}$ & $2(11 \%)$ & $5(10 \%)$ & $9(16 \%)$ & $1(11 \%)$ \\
\hline $\begin{array}{l}\text { That your library has an adequate } \\
\text { librarywide diversity program? }\end{array}$ & $8(42 \%)$ & $21(43 \%)$ & $23(40 \%)$ & $1(11 \%)$ \\
\hline
\end{tabular}


TABLE 6

Number and Percent of Male and Female

Respondents and the Six Factors of Concern $(\mathrm{N}=129)$

\section{Gender \\ Total No. of Respondents*}

Isolation in workplace

Isolation in institution

Isolation affects performance

Incidences of racial discrimination

Hostile work environment

Adequate diversity program

*This table includes those respondents who reported moderate and to a high degree. Other choices included "no opinion," "little," and "not at all."

felt that the library had no adequate diversity program.

Table 6 shows gender and the six factors of concern. For all six factors, a higher percentage of women responding to each question indicated that the factor was significant in their areas. For example, 37 percent of the females felt isolated in the workplace, compared to 23 percent of the males. Likewise, 44 percent of the females felt isolated at the institution, compared to 30 percent of the males.

Table 7 shows correlates of years as a professional librarian with the six factors of concern. Librarians with 0-3.9, ten to fifteen, and more than fifteen years of experience felt a moderate to high degree of the group with more than fifteen years of experience. Incidences of racial discrimination were felt more in the groups with ten to fifteen or more years of experience. Nine members of the group with fewer than four years of experience reported incidences of racial discrimination. Seven of the thirty-four librarians with ten to fifteen years of experience reported a moderate to high degree of hostility in the work environment. Of the forty-seven respondents with more than fifteen years of experience, thirty-one reported that the library's diversity program was not adequate.

Table 8 shows years as a professional librarian at the present institution corre-

TABLE 7

Number and Percent of Respondents for Years of Experience and the Six Factors of Concern $(\mathrm{N}=132)$

\begin{tabular}{lcccc}
\hline Years of Experience & $\mathbf{0 - 3 . 9}$ yrs & $\mathbf{4 - 9 . 9}$ yrs & $\mathbf{1 0 - 1 5}$ yrs. & $\begin{array}{c}\text { More than } \\
\mathbf{1 5} \text { yrs. } \\
\text { No. of Respondents* }\end{array}$ \\
\hline Isolation in workplace & $\mathbf{2 9}$ & $\mathbf{2 2}$ & $\mathbf{3 4}$ & $\mathbf{4 7}$ \\
Isolation in institution & $14(48 \%)$ & $5(23 \%)$ & $14(41 \%)$ & $14(30 \%)$ \\
Isolation affects performance & $16(55 \%)$ & $5(22 \%)$ & $14(41 \%)$ & $19(40 \%)$ \\
Incidences of racial discrimination & $7(24 \%)$ & $6(27 \%)$ & $5(15 \%)$ & $7(15 \%)$ \\
Hostile work environment & $9(31 \%)$ & $4(18 \%)$ & $11(32 \%)$ & $11(23 \%)$ \\
Adequate diversity program & $11(38 \%)$ & $4(18 \%)$ & $7(20 \%)$ & $5(11 \%)$ \\
& $11(50 \%)$ & $10(29 \%)$ & $16(34 \%)$
\end{tabular}

*This table includes those respondents who reported moderate and to a high degree. Other choices included "no opinion," "little," and "not at all." 


\begin{tabular}{|c|c|c|c|c|c|}
\hline \multicolumn{6}{|c|}{$\begin{array}{c}\text { TABLE } 8 \\
\text { Number and Percent of Years at Present Institution }(N=135)\end{array}$} \\
\hline $\begin{array}{l}\text { Years at Present } \\
\text { Institution } \\
\text { No. of Respondents* }\end{array}$ & $\begin{array}{l}\text { Less than } \\
1 \text { year } \\
13\end{array}$ & $\begin{array}{c}\text { 1-3.9 yrs. } \\
35\end{array}$ & $\begin{array}{c}\text { 4-9.9 yrs. } \\
38\end{array}$ & $\begin{array}{c}10-15 \text { yrs. } \\
25\end{array}$ & $\begin{array}{c}\text { More than } \\
15 \text { yrs. } \\
24\end{array}$ \\
\hline Isolation in workplace & $9(69 \%)$ & $14(40 \%)$ & $11(29 \%)$ & $8(32 \%)$ & $5(21 \%)$ \\
\hline Isolation in institution & $9(69 \%)$ & $17(48 \%)$ & $13(34 \%)$ & $9(36 \%)$ & $7(30 \%)$ \\
\hline $\begin{array}{l}\text { Isolation affects } \\
\text { performance }\end{array}$ & $3(23 \%)$ & $10(28 \%)$ & $7(18 \%)$ & $4(16 \%)$ & $2(8 \%)$ \\
\hline $\begin{array}{l}\text { Incidences of racial } \\
\text { discrimination }\end{array}$ & $4(31 \%)$ & $6(17 \%)$ & $11(29 \%)$ & $7(28 \%)$ & $8(33 \%)$ \\
\hline $\begin{array}{l}\text { Hostile work } \\
\text { environment }\end{array}$ & $2(15 \%)$ & $2(5 \%)$ & $6(16 \%)$ & $5(2 \%)$ & $3(12 \%)$ \\
\hline $\begin{array}{l}\text { Adequate diversity } \\
\text { program }\end{array}$ & $6(46 \%)$ & $19(54 \%)$ & $16(42 \%)$ & $8(32 \%)$ & $5(21 \%)$ \\
\hline
\end{tabular}

lated with the six factors of concern. The groups with 0-3.9 and 4-9.9 years of experience felt more isolation in the workplace and at the institution. Isolation affected the performance of the group with 1-3.9 years of experience more than it did any other group. The group with more than fifteen years of experience experienced more incidences of racial discrimination. The groups with ten to fifteen and more than fifteen years of experience felt that the library's diversity program was not adequate.

When asked, "Within the past two years, have you considered leaving your present position?" 54 of the 136 respondents responded no and 79 responded yes. Three respondents provided no responses, with one indicating that she had been on the job less than a year and another indicating that she had recently received a promotion.

The seventy-nine librarians who had considered leaving their jobs in the past two years were asked to rank the factors that would influence their decision to leave. The most frequently cited reasons for leaving included professional opportunities, with twenty-seven individuals ranking it first and fourteen individuals ranking it second. Twenty-two individu- als ranked salary as the second reason for leaving and eleven ranked it third. Sixteen librarians ranked work environment as the third reason for leaving, while eleven ranked it as the first reason. Job no longer challenging was ranked as the fourth reason for leaving by ten librarians, and first and second by eight librarians. Nine librarians cited the library not being committed to diversity as the fourth reason for considering leaving their position.

Respondents were asked to list occurrences in their current job that contributed significantly to their feeling of satisfaction. The top ten included: (1) supportive colleagues, (2) good supervisors, (3) professional assignment participation, (4) availability of technology and resources, (5) work environment, (6) opportunity to advance, (7) variety of job assignments, (8) salary and benefits, (9) interaction with faculty and students, and (10) challenging tasks.

When asked to list occurrences in their job that contributed significantly to their feeling of dissatisfaction, respondents identified these factors: (1) threatening, oppressive environment, (2) lack of respect and acceptance by colleagues and library administration for contribution to 
the organization, (3) few African American librarians, (4) isolation, (5) racism, (6) being assigned many clerical duties, (7) turf wars, (8) daily, unthinking anti-black statements, (9) communication with library administration, and (10) patrons' reluctance to seek assistance when supervising the reference desk.

Comments were few. Most wanted to see the results of the survey. Some of the specific comments were:

- "There are few Hispanic librarians."

- "Colleagues underestimate my qualifications."

- "Colleagues don't accept my abilities and contributions at par with their own."

- "My environment is almost exclusively white and I find that whites are frequently mean and hostile to one another, so it is often difficult to tell when an unpleasant or negative situation is due to simple human orneriness and when it is due to racism."

- "There are a few individuals who seem bigoted, but that isn't uncommon, nothing I can't deal with."

- "Isolated and undervalued."

- "Don't feel comfortable in communicating with others in the organization."

- "Colleagues do not want to learn of black resources, but send patrons to me for assistance."

- "Good work environment."

- "Hierarchy is complex."

- "Researcher should have used the term African rather than 'other' used in question 2."

- "No negative feeling as a person of color."

- "African American librarians are hesitant to leave familiar surrounding to seek new employment opportunities."
- "Need to get more African American students in library school."

- "Very pleased with support for research endeavor equipment and liberal travel policy."

- "Need to do more in recruiting."

\section{Conclusion}

This study identifies some of the sources of dissatisfaction and points out areas of satisfaction of librarians of African descent. By using the results of this study, library managers may address the areas of dissatisfaction and capitalize on areas of satisfaction. Understanding the factors that influence job satisfaction generally, and for librarians of African descent specifically, can contribute significantly to the recruitment and retention of this group of librarians. It is imperative that more research be conducted in this area

It also is clear from this study that African American librarians in ARL universities are an aging group. It is time for library managers to aggressively recruit additional librarians of African descent to the profession and to improve their opportunities for growth and advancement in the field. Library managers also need to work harder at retaining current minority librarians.

As this survey shows, librarians of African descent who are satisfied with their jobs will stay in them longer. Job satisfaction studies of librarians of African descent in other library consortia are needed.

It is time to take the necessary steps to create a work environment that attracts and enhances the job satisfaction of not only librarians of African descent, but all librarians of color.

\section{NOTES}

1. Carol Patitu and Martha Tack, "Job Satisfaction of African-American Faculty in Higher Education in the South" (paper presented at the Annual Meeting of the Association for the Study of Higher Education, Boston, 1991). ERIC ED 339318.

2. William B. Harvey, "Where Are the Black Faculty Members?" Chronicle of Higher Education 31, no. 19 (Jan. 22, 1986): 96.

3. Earl Smith and Stephanie Witt, "A Comparative Study of Occupational Stress among 


\section{Job Satisfaction of Librarians of African Descent 231}

African American and White University Faculty: A Research Note," Research in Higher Education 34 (Apr. 1993): 229-41.

4. Association of Research Libraries, Annual Salary Survey, 1987-1997 (Washington, D.C.: ARL, 1987-1997).

5. Jan S. Squire, "Job Satisfaction and the Ethnic Minority Librarian," Library Administration $\mathcal{E}$ Management 5 (fall 1991): 194-203.

6. Meredith A. Butler and Gloria R. Desole, "Creating the Multicultural Organization-A Call to Action," in Libraries as User-Centered Organizations: Imperatives for Organizational Change, ed. Meredith A. Butler (New York: Haworth Pr., 1993), 155-74.

7. DeEtta Jones, "ALA Defines Important New Strategy to Increase Minorities in Library Professions, ARL: A Bimonthly Newsletter of Research Library Issues and Actions 190 (Feb. 1997): 13.

8. Johannah Sherrer, "Job Satisfaction among Colorado Library Workers," Colorado Libraries 11 (June 1985): 17-21.

9. William J. Vaughn and J. D. Dunn, "A Study of Job Satisfaction in Six University Libraries," College \& Research Libraries 35 (May 1974): 163-77.

10. Subodh Nandy, "Job Satisfaction of the Library Professionals," Herald of Library Science 24 (Oct. 1985): 295-300.

11. Paul E. Spector, "Measurement of Human Service Staff Satisfaction: Development of the Job Satisfaction Survey," American Journal of Community Psychology 13 (Dec. 1985): 693-713.

12. Louis Nourse, "Speaking for the Dissatisfied Young Assistant," ALA Bulletin 31 (Oct. 1937): 629-34; R. C. Hoage, "Resignation in Two University Libraries," College \& Research Libraries 11 (Jan. 1950): 28-32, 39.

13. Beverly Lynch and Jo Ann Verdin, "Job Satisfaction in Libraries: Relationships of the Work Itself, Age, Sex, Occupational Group, Tenure, Supervisory Level, Career Commitment, and Library Department," Library Quarterly 53 (Oct. 1983): 434-47; Norman Roberts, "Graduates in Academic Libraries: A Survey of Past Students of the Post-Graduate School of Librarianship and Information Science, Sheffield University, 1964/65-1970/71," Journal of Librarianship 5 (Apr. 1973): 97-115; Lawrence D. Prybil, "Job Satisfaction in Relation to Job Performance and Occupational Level," Personnel Journal 52 (Feb. 1973): 94-100; Vaughn and Dunn, "A Study of Job Satisfaction in six University Libraries," 163-77; Kenneth Plate and Elizabeth Stone, "Factors Affecting Librarians' Job Satisfaction: A Report of Two Studies," Library Quarterly 44 (Apr. 1974): 97-110; Suzanne P. Wahba, "Job Satisfaction of Librarians: A Comparison between Men and Women," College E Research Libraries 36 (Jan. 1975): 45-51; Noragh Jones, Continuing Education for Librarians (Leeds: Leeds Polytechnic School of Librarianship, 1977), 132-51; Steven Chwe, "A Comparative Study of Job Satisfaction: Catalogers and Reference Librarians in University Libraries," Journal of Academic Librarianship 4 (July 1978): 139-43; George P. D'Elia, “The Determinants of Job Satisfaction among Beginning Librarians," Library Quarterly 49 (July 1979): 283-302; Richard Scamell and Bette Stead, "A Study of Age and Tenure as It Pertains to Job Satisfaction," Journal of Library Administration 1 (spring 1980): 3-18; Bette Stead and Richard Scamell, "A Study of the Relationship of Role Conflict, the Need for Role Clarity, and Job Satisfaction for Professional Librarians," Library Quarterly 50 (July 1980): 310-23.

14. Beverly Lynch and Jo Ann Verdin, "Job Satisfaction in Libraries: A Replication," Library Quarterly 57 (Apr. 1987): 190-202.

15. Ilene F. Rockman, "Job Satisfaction among Faculty and Librarians: A Study of Gender, Autonomy, and Decision-Making Opportunities," Journal of Library Administration 53 (fall 1984): $43-56$.

16. Carol Saunders and Russell Saunders, "Effects of Flextime on Sick Leave, Vacation Leave, Anxiety, Performance, and Satisfaction in A Library Setting," Library Quarterly 55 (Jan. 1985): 7188.

17. Dale Susan Bengston and Dorothy Shields, "A Test of Marchant's Predictive Formulas Involving Job Satisfaction," Journal of Academic Librarianship 11 (May 1985): 88-92.

18. Kamala Chopra, "Job Satisfaction among the Librarians of Lucknow City," Herald of Library Science 23 (July/Oct. 1984): 156-61.

19. Brigg Nzotta, "Factors Associated with the Job Satisfaction of Male and Female Librarians in Nigeria," Library and Information Science Research 7 (Jan.-Mar. 1985): 75-84.

20. - "A Comparative Study of the Job Satisfaction of Nigerian Librarians," International Library Review 19 (Apr.1987): 161-73.

21. J. F. Shyu, "A Study on Job Satisfaction of the University Library Staff," Journal of Library and Information Science 11 (1985): 207-34.

22. David Waters, "New Technology and Job Satisfaction in University Libraries," LASIE 18 (Jan./Feb. 1988): 103-8.

23. Edet E. Nkereuwem, "The Correlation between Job Satisfaction, Job Attitude and Work Behavior among the Staff in Academic Libraries in Nigeria," Information Service and Use 12 (1992): 
253-61.

24. Nancy Washington, "Focus on the Academic Librarian: Job Satisfaction and Continuing Education Goals," Southeastern Librarian 39 (fall 1989): 103-5.

25. Leigh Estabrook, Chloe Bird, and Frederick Gilmore, "Job Satisfaction: Does Automation Make a Difference?" Journal of Library Administration 13, no. 1/2 (1990): 175-79; Jo Bell Whitlach, "Automation and Job Satisfaction among Reference Librarians," Computers in Libraries 11 (Sept. 1991): 32.

26. Tina Hovekamp, "Unionization and Job Satisfaction among Professional Library Employees in Academic Research Institutions," College E Research Libraries 56 (July 1995): 341-50.

27. Jack A. Siggins, "Job Satisfaction and Performance in a Changing Environment," Library Trends 41 (fall 1992): 299-315.

28. Patricia Kreitz and Annegret Ogden, "Job Responsibilities and Job Satisfaction at the University of California Libraries," College $\mathcal{E}$ Research Libraries 51 (July 1990): 297-312.

29. Donna Fitch, "Job Satisfaction among Library Support Staff in Alabama Academic Libraries," College E Research Libraries 51 (July 1990): 313-20; C. D. Billings and B. Kern, "Sources of Satisfaction and Dissatisfaction among Library Paraprofessionals," LLA Bulletin 52 (1990): 17178; Coleen Parmer and Dennis East, "Job Satisfaction among Support Staff in Twelve Ohio Academic Libraries," College E Research Libraries 54 (Jan. 1993): 43-57; Samuel Oladokun, "A Survey of Job Satisfaction among Library Officers in Nigeria," Library Review 42 (1993): 38-43; Cathleen C. Palmini, "The Impact of Computerization on Library Support Staff: A Study of Support Staff in Academic Libraries in Wisconsin," College E Research Libraries 55 (Mar. 1994): 119-27; Julie Voelck, "Job Satisfaction among Support Staff in Michigan Academic Libraries," College E Research Libraries 56 (Mar. 1995): 157-70; A. P. N. Thapisa, "The Burden of Mundane Tasks: Library Assistants' Perceptions of Work," British Journal of Academic Librarianship 4 (1989): 137-60; , "The Motivation Syndrome: Job Satisfaction through the Pay Nexus," International Library Review 23 (Apr. 1991): 141-58; Edet E. Nkereuwen, "The Correlation between Job Satisfaction, Job Attitudes and Work Behavior among the Staff in Academic Libraries in Nigeria," Information Services and Use 12 (1992): 253-61.

30. Anne Goulding, "I Want to Work with Books and People: The Job Satisfaction of Public Library Support Staff," Public Library Journal 10 (May/June 1995): 71-74; Margaret S. Schneider, "Stress and Job Satisfaction among Employees in a Public Library System with a Focus on Public Service," Library \& Information Science Research 13 (Feb. 1991): 385-404; Anne Goulding, "Managing the Job Satisfaction of Public Library Paraprofessionals in a Changing Climate," Public Library Journal 6 (July/Aug. 1991): 93-99; Hye Lee and Mary Kim, "The Relationship between Quality of Goal Setting and Job Satisfaction in a Public Library Setting," Public Library Quarterly 13 (1993): 41-57.

31. Mohammad H. Mirfakhrai, "Correlates of Job Satisfaction among Academic Librarians in the United States," Journal of Library Administration 14, no. 1 (1991): 117-31.

32. Squire, "Job Satisfaction and the Ethnic Minority Librarian," 194-203.

33. Estabrook, Bird, and Gilmore, "Job Satisfaction," 175-79.

34. Cynthia Preston, "Perceptions of Discriminatory Practices and Attitudes: A Survey of African American Librarians, College E Research Libraries 59 (Sept. 1998): 434-45.

35. Bonnie Horeinstein, "Job Satisfaction of Academic Librarians: An Examination of the Relationship between Satisfaction, Faculty Status, and Participation," College E Research Libraries 54 (May 1993): 255-69.

36. Association of Research Libraries, Annual Salary Survey 1996-97 (Washington, D.C.: ARL, 1997), 12.

37. Joan Howland, "Beyond Recruitment: Retention and Promotion Strategies to Ensure Diversity and Success, Library Administration \& Management 13 (winter 1999): 4-14.

38. Preston, "Perceptions of Discriminatory Practices and Attitudes," 441. 